\title{
Status of plankton diversity and biological productivity of Sahastradhara stream at Uttarakhand, India
}

\author{
D. S. M alik* and Umesh Bharti \\ Department of Zoology and Environmental Science,Gurukula Kangri University, Haridwar (U.K.) INDIA \\ *Corresponding author. E-mail: malikdsgkv@gmail.com
}

\begin{abstract}
The present contribution encompasses on plankton and biological productivity as ecological indicator for identifying the ecological quality of Sahastradhara stream (between $27 \mathrm{~km}$ stream stretches), located in the Doon Valley of Garhwal region in India. Monthly sampling from all the sampling sites was made for a period of 12 months (May 2009 - April 2010) at 9:00-11:00 AM. A total of 40 taxa from different classes of plankton and zooplankton were reported. The phytoplankton (32 sp.) was found being the most abundant taxa than zooplankton (9 sp.) in Sahastradhara stream. Fluctuation in the phytoplankton density was recorded highest (1536 unit/l) during winter and lowest (20 unit//) during monsoon. Zooplanktons were reported to be maximum (147 unit/l) during summer and minimum (3 unit//) during monsoon. The total diatoms were reported highest (1022unit/l) during starting the winter and lowest (4 unit/l) during monsoon. Green algae and blue green algae were reported to be maximum during winter and minimum during summer. The Shannon-wiener diversity index calculated for the density of Bacillariophyceae (0.2180-0.366), Chlorophyceae (0.208-0.367) and Cyanophyceae (0.391-0.366) and correlation was made between Plankton biomass and physico-chemical parameters to analyses the relative features of the both variables. The density of plankton and biological productivity were influenced by disturbances in the photic zone and indiscriminate anthropogenic activities for tourist development resulted aquatic habitat degradation in stream ecosystem.
\end{abstract}

Keywords: Biological productivity, Ecological indicator, Habitat degradation, Plankton.

\section{INTRODUCTION}

Biological assessment is a significant alternative for assessing the ecological quality of aquatic ecosystems since biological communities integrate the environmental effects of water chemistry of rivers and hill streams (Stevenson and Pan, 1999). Plankton encountered in the water body reflects existed ecological characteristics and therefore, plankton organisms may be used as indicators of water quality (Bhatt et al., 1999; Saha et al., 2000). In hill streams, a great variation in the composition of plankton occurred not only in different regions on different depths but also at different periodically time scales and seasons. The majorities of phytoplankton are non-motile and very sensitive to change in the environmental conditions due to water turbulence along with other ecological factors in upper water masses and contributed alteration in existed aquatic habitat. The conditions that lead to maxima and minima, as well as to minor fluctuations in abundance of phytoplankton are complex in their physical, chemical and biological characteristics. A considerable amount of research work has been done in different fresh water bodies in relation to phytoplankton (Calijuri et al., 2002 and Angadi et al., 2005). The several qualitative observations and reports are available on both lotic and lentic aquatic ecosystems, especially in Garhwal region of Himalaya. Such ecological studies have been initiated recently in the Himalayan streams, which have global importance to biological productivity in relation to biodiversity (Nautiyal 1986; Dobriyal and Singh 1989; Ormerod et al., 1997; Pathani and Mahar 2006; Bhutiani and Khanna 2007). The present study was conducted to examine the interaction of plankton community and water quality in a hill stream (Sahastradhara) influenced due to many anthropogenic activities and municipal wastes dumped into its stream channels at different sites..

\section{MATERIALS AND METHODS}

The present study was conducted on the famous sulphur stream 'Sahastradhara' at Dehradun during 2009 - 10. Geographically, Garhwal has almost central position in the long Himalayan sweep, it is the most important part of lesser Himalaya, which lies between latitudes $29^{\circ} 26^{\prime}$ to $31^{\circ} 28^{\prime} \mathrm{N}$ and longitude $77^{\circ} 49^{\prime}$ to $80^{\circ} 06^{\prime}$. The samples were collected from five different sites at stretches of about $27 \mathrm{~km}$ area from the surface water samples to analyzed plankton biomass and phytoplankton species composition. Plankton samples (phytoplankton and zooplankton) collected monthly from May 2009 to April 2010. Regular monthly samples were undertaken between 9:00 - 11:00 AM from each site throughout the study 
period. Ten liters of water from each sites were filtered through plankton net (Mesh size No. 20) to get the plankton and preserved immediately in $100 \mathrm{ml}$. plastic bottle by using $4 \%$ formalin.

Preserved algal samples were scanned under microscope, measured by micrometer and identified. Phytoplankton species composition was examined from preserved water sample in acid Lugol's solution. Units greater than $1 \mu \mathrm{m}$ in diameters (depending on the species) were identified to genus level by electron microscope (Model no. $\mathrm{CH}$ 20i, Olympus). Algal taxa were identified by the keys mentioned as Edmondson (1992). Different algal groups counted separately by using Sedgwick-rafter cell. Statistical mean and standard deviation (S.D.) were calculated using standard software packages (MicrosoftExcel). Diversity index Shannon - Weaver (1949) and correlation coefficient were also calculated. Shannon Weaver diversity index $\left(\mathrm{H}^{\prime}\right)$ was calculated using the following formula:

$$
\text { Shanon - Weaver index }(\mathrm{H})=\Sigma \frac{\mathrm{ni}}{\mathrm{N}} \ln \frac{\mathrm{ni}}{\mathrm{N}}
$$

Where, $\mathrm{H}=$ Shannon -Weaver index of diversity; ni = total numbers of individuals of species, $\mathrm{N}=$ total number of individual of all species.

\section{RESULTS}

Hill streams are generally the important source of natural water and provide a life support ecosystem for existed biodiversity in aquatic ecosystem. The process of economic growth and development, virtually have inverse relationships with hill stream resources and quality of aquatic environment. Generally, plankton are heterogeneous minute organism occurred in natural water and float on the wave action and movement of water. The present study focused on the fluctuation in planktonic biomass with the productivity pattern and correlation with water quality characteristics that indicated direct relation of particular variable for the growth of existing biomass of planktons in the stream ecosystem. Algal flora, periodical abundance and dominance of phytoplankton of Sahastradhara stream have been presented in Tables 1 to 6 . The study of plankton has shown the presence of 32 taxa of 4 different classes and 9 taxa were recorded as zooplankton from different sampling sites (Table 5 and 6). Planktonic biomass was recorded maximum during the months of February and March and minimum in the months of June September at all sites. Overall planktonic biomass observed higher at sampling station $\mathrm{S}_{1}$ and lower at $\mathrm{S}_{2}$ followed by $\mathrm{S}_{5}, \mathrm{~S}_{4}$ and $\mathrm{S}_{3}$. Seasonal density of phytoplankton in the Sahastradhara stream has shown in Table 5. The stream comprises the maximum density of phytoplankton during winter (1529 unit/l) when turbidity and velocity of water were low in their volume and the minimum value of phytoplankton (20 units/l) was recorded during monsoon months due to high turbidity and high water velocity of stream.

At site $S_{1}$ (Karligarh), the total planktonic concentration was recorded as phytoplankton (75-1536 unit/l), zooplanktons (25- 97 unit/l), total diatoms (28 - 1022 unit/l), green algae (98 - 237 unit/l) and blue green algae (26 - 110 unit/l) and gross productivity was reported highest $(0.998 \pm 0.03 \mathrm{mg} / \mathrm{l})$ during April month and lowest $(0.343 \pm 0.03 \mathrm{mg} / \mathrm{l})$ during June. The primary productivity of stream controlled by several inhabiting ecology of water bodies and considered as direct manifestation of the productivity. In this regards, the biological productivity and net production efficiency were observed 37.24 and $45.69 \%$ during September and April respectively. A irregular ecological change was reported in plankton and productivity pattern at site $\mathrm{S}_{2}$ (tourist spot) therefore, phytoplankton reported as 25 - 1408 unit/ 1, zooplanktons as 3 - 148 unit/l, total diatoms ranged as 310 - 987 unit/l, green algae as 102 - 238 unit/l and blue green algae ranged as $21-87$ unit/l (Table 1). The gross productivity was reported as 0.318 to $1.159 \mathrm{mg} / \mathrm{l}$ and net production efficiency $(\%)$ was reported in the ranged of 18.03 to $66.67 \%$, which recorded lowest in comparisons to other sites (Table 2).

The minimum values of planktonic biomass affected mainly due to anthropogenic activities like bathing, washing and canalization of stream water to make small ponds to attract the tourists for bathing activities and construction of hotel near by bank of stream creating imbalance in low flow water velocity current. A sudden change was reported in total plankton concentration from site $S_{3}$ to downstream site $S_{5}(11-1501$ unit/l), gross productivity and net production efficiency $\%$ was ranged as $0.358-0.953 \mathrm{mg} / \mathrm{l}$ and $37.09-58.16(\%)$ respectively (Table 2).

An inverse relationship was found between physicochemical parameters and planktonic biomass. Phytoplankton showed the negative correlation with temperature $(-0.8), \mathrm{pH}(-0.85)$, alkalinity $(-0.89), \mathrm{CO}_{2}(-$ $0.04)$, BOD (-0.92), calcium (-0.99), magnesium $(-0.72)$, sodium (-0.95), potassium (-0.92) and chloride (-0.95). However, a positive relationship was found with velocity (0.01) and DO (0.97) which indicated that planktonic growth depend on DO and well sustain water flow. Other hand, zooplanktons showed inverse correlation with DO $(-0.83)$ and positive relationship with temperature $(\mathrm{r}=0.51)$, velocity $(\mathrm{r}=0.38), \mathrm{pH}(\mathrm{r}=0.98)$, alkalinity $(\mathrm{r}=0.36)$, $\mathrm{CO}_{2}(\mathrm{r}=0.99), \mathrm{BOD}(\mathrm{r}=0.97), \mathrm{Ca}(\mathrm{r}=0.91), \mathrm{Mg}(=0.99)$, $\mathrm{Na}(\mathrm{r}=0.99), \mathrm{K}(\mathrm{r}=0.99)$ and $\mathrm{Cl}^{-}$.

Further, the planktonic community consists of the members of Chlorophyceae (12 sp.), Bacillariophyceae (11 sp.), Cyanophyceae (7 sp.) and Euglenophyceae (2 sp.) and zooplanktons comprised protozoa (4 sp.), rotifers 


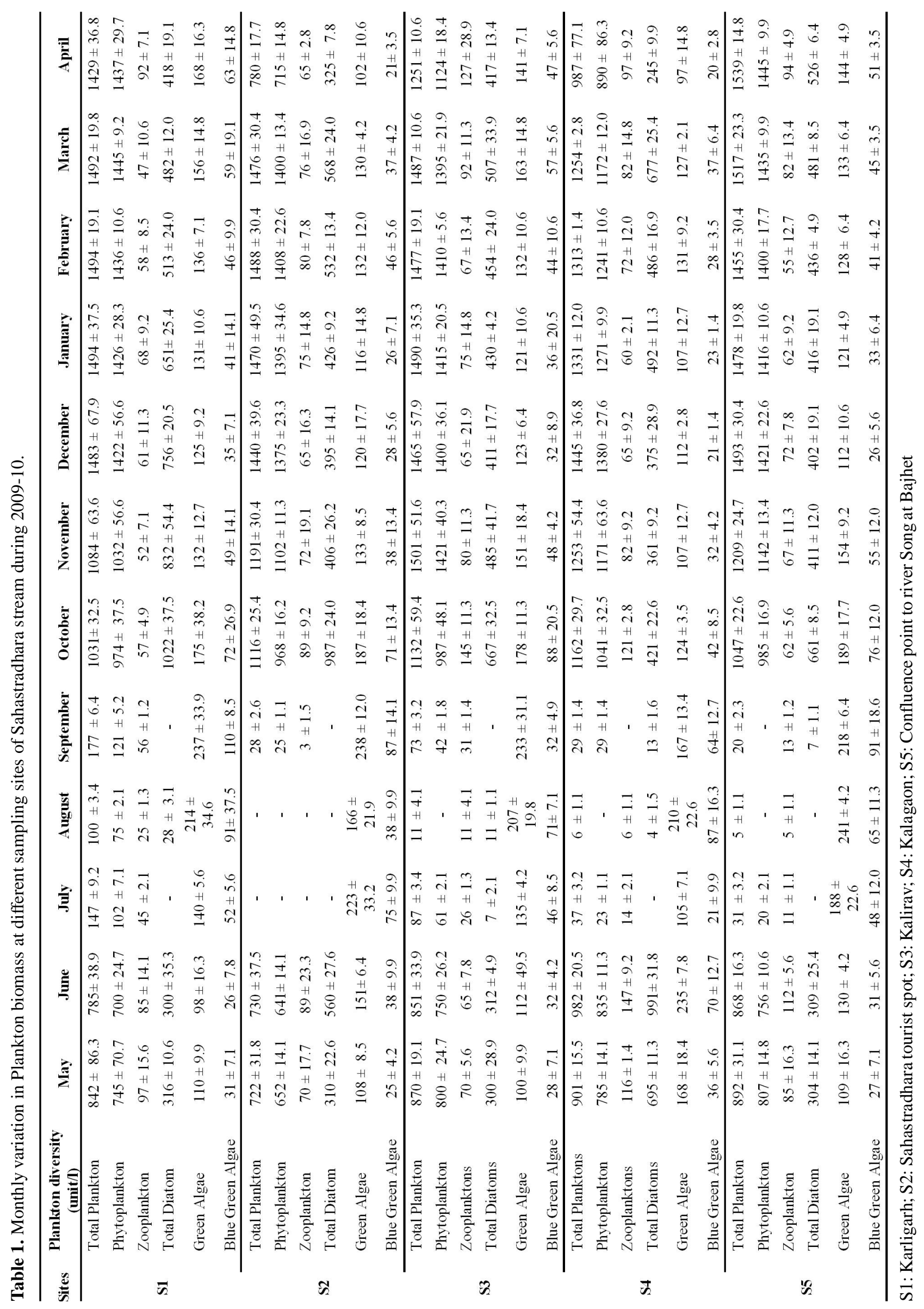




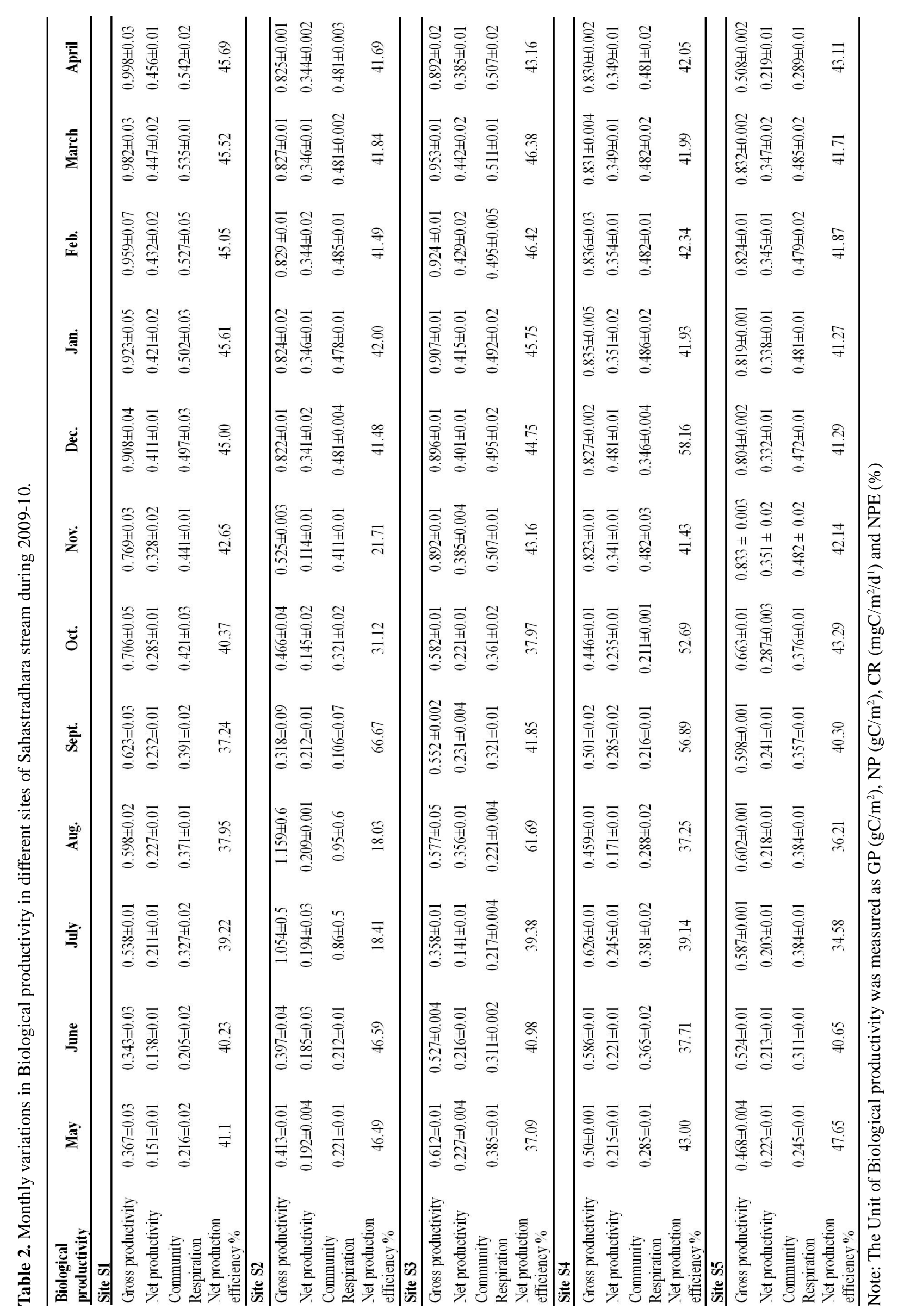




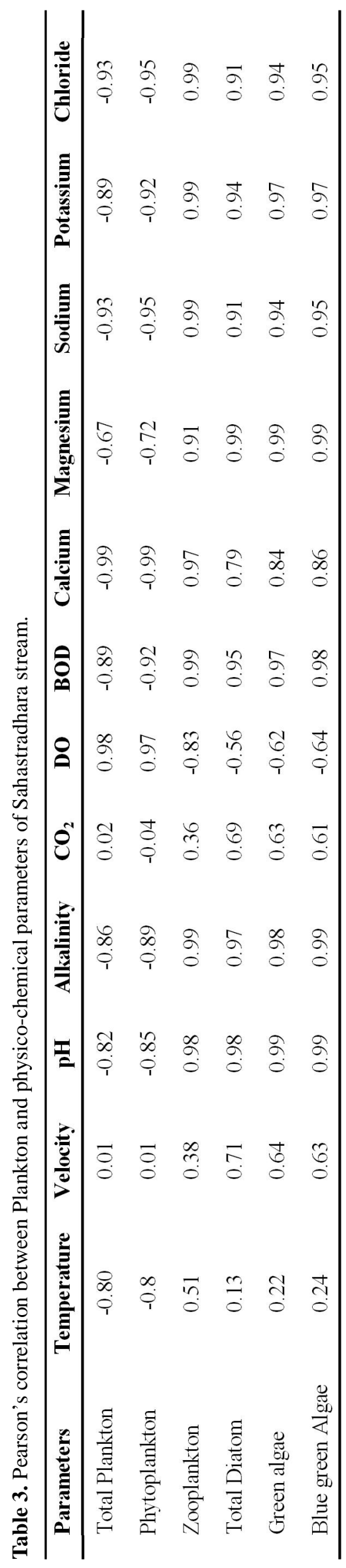

(2 sp.), cladocera (2 sp.) and copepoda (1 sp.) (Table 5 and 6) were identified from all five different sampling stations and their density was showed low trend during the rainy season due to high current speed creating wash out effect. The occurrence of Bacillariophyceae were observed dominant group during winter. Fragillaria, Gomphonema, Nitzschia, Navicula, Diatoms and Cymbella species were recorded dominating sp. during winter at each site. Chlorophyceae, occurred maximum during winter and minimum in monsoon. Zygnema were recorded as dominating species followed by Ulothrix, Spirogyra, Cholorella, Clodophora Volvox, and Closterium species. Spirulina and Aphanizomenon species were observed as dominating species as Cyanophyceae. Anabena Nostoc and Nadularia species were found common during summer and monsoon respectively. Euglena was reported absent during monsoon but showed maximum density during winter and summer (Table 5).

The Shannon diversity of stream for different sites were calculated as Bacillariophyceae $(0.218-0.366)$, Chlorophyceae $(0.208$ - 0.367$)$ and $C$ yanophyceae $(0.291$ - 0.366) respectively, indicated the quite correlation-ship with overall species richness across the sites and may be required to best management by the biodiversity conservation managers for conservation and habitat restoration.

Among phytoplankton diversity, Bacillariophyceae showed the minimum diversity index value $(0.218)$ at site $\mathrm{S}_{2}$ due to the anthropogenic activities, canalization and fragmentation of stream way, which provided different aquatic barriers into the flow of the water and maximum diversity (0.366), was reported at site $S_{1}$ due to no irregularity in stream flow and less human interference. The Chlorophyceae showed the diversity index (0.208) at site $S_{2}$ and maximum $(0.367)$ at site $S_{1}$. C yanophyceae presented minimum value of diversity index (0.291) at site $\mathrm{S}_{5}$ that may be due to less photic zone and less depth of water, stagnant flow and maximum value of diversity index (0.366) at site $S_{1}$ which may be due to the presences of rich habitat niche, less human interferences, medium flow of water and high DO level (Table 4).

\section{DISCUSSION}

Plankton are very sensitive to change as their species replacement with the altering of environmental conditions in aquatic ecosystem and exhibited the present status of ecological and biological characteristics of aquatic ecosystem specially in hill streams.

The present study indicated that the overall occurrence of phytoplankton density was maximum (1445 unit/l \pm $56.6)$ in winter and minimum (20 unit/l \pm 2.1$)$ in monsoon months due to the blanketing effect caused by the velocity in Sahastradhara Hill stream. It has been monitored during 
Table 4. Shannon - Weaver diversity index (mean value) of phytoplankton at different sampling sites in Sahastradhara stream.

\begin{tabular}{lccccc}
\hline Parameters/Sites & $\mathrm{S}_{1}$ & $\mathrm{~S}_{2}$ & $\mathrm{~S}_{3}$ & $\mathrm{~S}_{4}$ & $\mathrm{~S}_{5}$ \\
\hline Bacillariophyceae & 0.366 & 0.218 & 0.299 & 0.333 & 0.317 \\
Chlorophyceae & 0.367 & 0.208 & 0.283 & 0.316 & 0.335 \\
Cyanophyceae & 0.366 & 0.316 & 0.315 & 0.332 & 0.291 \\
\hline
\end{tabular}

Table 5. Diversity and seasonal abundance of phytoplankton dwelling in Sahastradhara stream during 2009-10.

\begin{tabular}{|c|c|c|c|}
\hline Taxon & Summer & M onsoon & W inter \\
\hline \multicolumn{4}{|l|}{ Chlor ophyceae } \\
\hline Closterium spp. & ++ & + & + \\
\hline Cladophora & ++ & - & ++ \\
\hline Chlorella & ++ & + & ++ \\
\hline Draparnaldia & + & - & ++ \\
\hline Hydrodictyon & ++ & + & - \\
\hline Microspora & + & - & ++ \\
\hline Oedogonium & ++ & - & + \\
\hline Spirogyra & ++ & - & ++ \\
\hline Tetraspora & - & - & ++ \\
\hline Ulothrix & ++ & - & ++ \\
\hline Zygnema & - & - & +++ \\
\hline Volvox & ++ & - & +++ \\
\hline \multicolumn{4}{|l|}{ Bacillariophyceae } \\
\hline Achnanthes devei & ++ & + & ++ \\
\hline A. bisoletiana & + & - & ++ \\
\hline Cymbella affinis & + & + & +++ \\
\hline Cocconies spp. & ++ & - & ++ \\
\hline Cyclotella & - & - & + \\
\hline Diatoms & ++ & - & +++ \\
\hline Fragillaria pinnata & - & ++ & +++ \\
\hline Gomphonema longiceps & - & + & +++ \\
\hline Nitzschia spp. & + & - & +++ \\
\hline Synedra rumpens & - & - & ++ \\
\hline Navicula spp. & + & - & +++ \\
\hline \multicolumn{4}{|l|}{ Cyanophyceae } \\
\hline Aphanizomenon & ++ & + & +++ \\
\hline Anabena spp. & + & + & - \\
\hline Nostoc spp. & ++ & + & + \\
\hline Nodularia & + & - & ++ \\
\hline O scillatoria spp. & ++ & ++ & - \\
\hline Spirulina & ++ & + & +++ \\
\hline Rivularia spp. & ++ & + & - \\
\hline \multicolumn{4}{|l|}{ Euglenophyceae } \\
\hline Euglena & + & - & ++ \\
\hline Peridium & ++ & + & ++ \\
\hline
\end{tabular}

Note: +++ Abundant; ++ Rare; + Common; - Absent.

the study time that water current remains above the moderate speed in usually directly inhibitory to plankton development. The abundance, quality of life and species richness are influenced by current velocity as stated by Crayton and Sommerfields (1979) in the tributaries of
Table 6. Diversity and seasonal abundance of zooplankton in Sahastradhara stream 2009-10

\begin{tabular}{lccc}
\hline Taxon & Summer & M onsoon & Winter \\
\hline Protozoan & & & \\
Arcella sp. & + & + & + \\
Paramecium sp. & ++ & - & + \\
Bursaria sp. & ++ & + & + \\
Vorticella & ++ & - & + \\
Rotifera & & & \\
Brachionus & ++ & - & + \\
Trichoceraca & + & - & ++ \\
Cladocera & & & \\
Daphnia & ++ & - & - \\
Basmina & ++ & - & ++ \\
Copepoda & & & \\
Cyclops & +++ & - & + \\
\hline
\end{tabular}

Note: +++ Abundant; ++ Rare; + Common; - Absent.

Colorada rivers. In the present study, phytoplankton was found to dominat over zooplankton. Bhowmick and Singh (1985) observed maximum density of phytoplankton during summer and minimum in monsoon months. Sharma et al. (2007) reported the fluctuation in phytoplankton diversity due to seasonal alteration in physico-chemical characteristics of surface water in the hill stream, Chandrabhaga of Garhwal Himalaya.

As the planktons in the hill streams varied in their density as the seasonal variation occurred, the results indicated that the plankton were maximumin winter months probably due to low temperature, high amount of dissolved oxygen and low velocity. The maximum density of phytoplankton during winter months have also been recorded by Chakraborty et al. (1959) and Pahwa and Mehrotra (1966) in river Jamuna and Ganga. The Biological productivity of stream controlled by several inhabiting ecology of water bodies and considered as direct manifestation of the productivity. In this regards, the biological productivity and net production efficiency calculated 37.24 and $45.69 \%$ during winter and summer months respectively. Such trend of concerning data of productivity was reported as plankton density (maximum in winter and minimum in summer and monsoon). In the present study, biological productivity was recorded higher range at upper stream and deep downstream. Minimum productivity pattern was observed at site $S_{2}$ that may be due to the anthropogenic activities and bathing activities along the stream belt. Maximum human interference was recorded as solid waste dumping, 
bathing and washing, hotel construction at this site. Khanna and Singh (2000) discussed the different aspects of planktonic diversity in Suswa river at Raiwala, Dehradun and stated that plankton biomass generally reported maximum during winter seasons, probably due to low temperature, high content of dissolved oxygen, low flow velocity and transparency of water. Pande and Mishra (2000) described the relationship in between the quality of surface water and biological productivity of shastradhara stream.

The physico-chemical characteristics of hill stream have significantly contributed to alter the magnitude of biological dynamics and showed interrelationship either positive or negative in existed ecosystem. The present co-relation coefficient showed the inverse relationship between phytoplankton and temperature, $\mathrm{pH}$, alkalinity, $\mathrm{CO}_{2}, \mathrm{BOD}, \mathrm{Ca}, \mathrm{Mg}$, sodium, potassium and chloride but showed the positive relationship with velocity and DO that indicated that plankton's growth depend on DO and the flow characteristic of running water. Similar findings supported to the surveyed work by Lakshminarayan and Someshekar (2001). Yeragi and Shaikh (2003) showed a good predication of correlation pattern between DO and production efficiency in Tansa river.

Shannon- Weaver index has been given a significant role as abundance of Chlorophyceae, Bacillariophyceae and $C$ yanophyceae at different sampling sites. Index showed maximum value (0.367) of Chlorophyceae at site $S_{1}$ that may be the result of less human interference, followed by Bacillariophyceae and Cyanophyceae $(0.366)$. The study indicated the quite correlation-ship with overall species richness across the sites and may be required to best managed by the biodiversity conservation managers for conservation and habitat restoration. Sharma et al., (2004) also found such kind of relation in aquatic organisms at Dhauli Ganga.

Rout and Gaur (1994) reported the Shannon diversity index as greater (1.6 - 4.1) in Shillong stream at Assam and higher indexing (2.6 - 4.1) was reported at Alps stream from upper parts of Himalaya by Cantonati et al. (2001). The present Shannon-Weaver diversity index showed the variability of water quality at all five different sites in Sahastradhara stream under the marginal pollution category.

The present study revealed that Sahastradhara hill-stream ecosystem carried high biological productivity in terms of better population density of different biotic communities including plankon, nekton, benthos and endemic fresh water fishes. Thus, the hill stream should be developed under protected area net work by conserving its biodiversity in protecting aquatic natural habitats of Doon valley in Garhwal Himalayan region.

\section{ACKNOWLEDGEMENTS}

The authors are highly grateful to University Grant
Commission, New Delhi for financial support to carry out the present research work.

\section{REFERENCES}

Angadi, S.B., Shiddamallayya, N. and Patil, P.C. (2005). Limnological studies of Papnash pond, Bidar (Karnataka). J. Environ. Biol., 26: 213-216.

Bhatt, L.R., Lacoul, P., Lekhal, H.D. and Jha, P.K. (1999). Physico-chemical characteristic and phytoplanktons for Taudha lake, Kathmandu. Poll. Res., 18 (4): 353-358.

Bhowmick,B.N. and Singh, A.K. (1985). Phytoplankton population in relation to physico-chemical factors of river Ganga at Patna. Indian J. Ecol., 12 (2) : 360-364.

Bhutiani, R. and Khanna, D.R. (2007). Ecological study of river Suswa: modeling DO and BOD. E nviron M onit Assess., 125:183-195.

Calijuri, M.C., Dos Santos ACA and Jati, S. (2002). Temporal changes in the phytoplankton community structure in a tropical and eutrophic Reservoir (Barra Bonita, S.P.-Brazil), J ournal of Plankton Research, 24: 617-634.

Cantonati, M., Corradini, G., Juttner, I. and Cox, E.J. (2001). Diatom assemblages in high mountain streams of the Alps and the Himalaya. B eiheft zur Nova Hedwigia., 123: 37-61.

Chakraborty, R.D., Roy. P. and Singh, S.B. (1959). A quantitative study of plankton and the physico-chemical condition of the river Yamuna at Allahabad in 1954-55. Indian J. Fish, 61: 186-208.

Crayton, W.M. and Sommerfiels, M.R. (1979). Composition an abundance of phytoplankton in tributaries of the lower Colorado river, Canyon region. H ydrobiologia, 66(1)81-93.

Dobriyal, A. K. and Singh, H. R. (1989). Observation on temporal trends of phytoplankton diversity in the river Nayar of Garhwal Himalaya. J. F resh water Biol., 1:1-6.

Edmondson, W. T. (1992). Fresh water biology second edition, pp. 1248.

Khanna, D. R. and Singh, R. K. (2000). Seasonal fluctuations in the plankton of Suswa river at Raiwala, Dehradun. Env. Conser vations J ., 1 (2 - 3): 89-92.

Lakshminarayana and Someshekar, R. K. (2001). Ecology of polluted water edited by Arvind Kunar Vol. I, Chapter II, APH Pub. Corp. New Delhi. pp.51-60.

Nautiyal, P. (1986). Studies on the riverine ecology of the torrential waters in Indian uplands of Garhwal regionFloristic faunistic survey. Trop. E col., 27:157-165.

Ormerod, S. J., Baral, H. S., Brewin, P. A., Buckton, S. T., Juttner, I., Rothfritz, H. and Suren, A.M. (1997). River habitat surveys and biodiversity in the Nepal Himalaya. In: Freshwater Quality: Defining the Indefinable, Boon P. J. \& Howell, D. L. eds. HMSO, Edinburgh. pp.640.

Pahwa, D. V. and Mehrotra, S. N. (1966). Observations in the abundance of plankton in relation to certain hydro-biological conditions of river Ganges. Proc Natl Acad Sci ., 36 (2): $157-$ 89.

Pande, R. K., and Mishra, A. (2000). Water quality study of freshwater of Dehradun (Sahastradhara stream and Mussoorie Lake). Aquacult., 1: 57-62.

Pathani, S. S. and Mahar, S. (2006). A study of population of plankton in the river Suyal of Uttranchal, India. Flora and Fauna, 11(2): 250-256.

Rout, J. and Gaur, J. P. (1994). Composition of dynamics of 
epilithic algae in a forest stream at Shillong (India). Hydrobiologia, 291: 61-74.

Saha, S. B., Bhattacharya, S. B. and Choudhary, A. (2000). Diversity of phytoplankton of a sewage pollution brackish water tidal ecosystem. J. Env. Biol., 21 (1) : 9-14.

Shannon, C.E. and Weaver, W. (1949). The Mathematical Theory of Communication, University of Illinois Press. Urbana, IL., USA.

Sharma RC, Bhanot G, and Singh D. (2004). Aquatic macroinvertebrate diversity in Nanda Devi Biosphere Reserve, India. Environmentalist, $24: 211-221$
Sharma, A., Sharma, R. C, and Anthwal, A. (2007). Monitoring phytoplankton diversity in the hill stream Chandrabhaga of Garhwal Himalaya. Life Science J ournal, 4: 80-84.

Stevenson, R. J. and Pan, Y. (1999). Assessing environmental conditions in Rivers and streams using diatoms, In: Stoermer, E. F. and Smol, J. P. (eds.) The diatoms. Applications for the environmental and earth sciences, Cambridge University Press, Cambridge. pp. $11-40$.

Yeragi, S. G. and Shaikh, N. (2003). Studies on primary productivity of Tansa river. J. Natcon., 15(1) : 125-130. 